Palestine Exploration Quarterly

\title{
The Churches of St. Martin and St. John the Evangelist
}

\section{J. E. Hanauer}

To cite this article: J. E. Hanauer (1893) The Churches of St. Martin and St. John the Evangelist, Palestine Exploration Quarterly, 25:4, 301-305, DOI: 10.1179/peq.1893.25.4.301

To link to this article: http://dx.doi.org/10.1179/peq.1893.25.4.301

曲 Published online: 20 Nov 2013.

Submit your article to this journal $\asymp$

Џ Article views: 3

Q View related articles $\sqsubset$ 
ground to the east of the Church of the Holy Sepulchre could not be shared by others whose archæological knowledge would have enabled them to compare and examine the ancient remains which were discovered. Nor is it possible, without a carefully-drawn diagram, to understand the features of the locality to which Mr. Schick calls our attention, and by which he endeavours to establish the authenticity of the traditional site. But there are two broad facts which he leaves out of consideration. If the spot now occupied by the Church of the Holy Sepulchre was without the city as it existed in the time of Our Lord, the area of the city itself must have been very small, and its capacity for rearing even a moiety of the population with which it is credited, simply impracticable. Besides this, a wall so drawn as to exclude the traditional site of Calvary would leave the highest ground immediately outside of what was a strongly fortified town. This would be utterly out of keeping with the most rudimentary ideas of a fortified place, and place it almost at the mercy of an attacking force. Surely the tracings of ancient walls considerakly beyond the limits of the present city most probably represent the limits of Jerusalem as it existed in the time of Our Lord.

I do not pretend to be an authority on the subject, but it has always appeared to me that the valley of the Son of Hinnom was the great burial-place of the Jews at that time, and there must have been the tomb of Joseph of Arimathea. From the judgment-seat of Pilate the transit would be easy to that locality through the gate leading from the south-eastern end of the valley of the Tyropœon, and there Simon the Cyrenian coming out of the country might have been met, who would bear the cross to a spot, which would answer all the conditions of the Gospel history. "The place of a skull" would hardly describe the form of the ground, but more probably the place of execution, and of the remains of the dead, which being used for these purposes was regarded as defiled by the Jewish people.

BatH, May, 1893.

\section{THE CHURCHES OF ST. MARTIN AND ST. JOHN THE EVANGELIST.}

By the Rev. J. E. Hanauer.

I.

Is the Quarterly Statement for April, 1893, there appeared an account of a remarkable double vault and colonnade in the Jewish quarter of Jerusalem. Mr. Schick, who has now visited and planned it, agrees with me in believing it to have formed part of the Church of St. Martin, which, after the expulsion of the Crusaders in 1187, seems to have been allowed to fall into ruin, and was then bought by the celebrated Nachmanides, and turned into a 
synagogue, A.D. 1227. Writing to his son, then living in Spain, Nachmanides says: "We found a very handsome but destroyed building with marble columns and a beautiful cupola, and started a collection in order to restore this edifice as a synagogue; after which we began at once to build up the same." (Rabbi Schwarz's "Das heilige Land," Frankfort-am-Main, 1852, p. 234.) Schwarz goes on to say that this building with columns and cupola still existed in 1852, and was known as "Al Maraga," but having been forcibly taken from the Jews about the year 5356, i.e., circa A.D. 1566. It was turned into a Ma'serah or place for the manufacture of dibs or grape molasses. The name "Maragha," or place where donkeys roll themselves, is in all probability derived from the word 'Moslems, one of whose peculiarities it is to try to turn Christian proper nouns into ridicule. As they applied the term "Al Kamamah," the dung hill, to the Church "Al Kiamah," or of the Resurrection, so the name El Martinieh or Mar Martin, suggested the offensive name "Al Maragha," which the double vault already alluded to still bears. Th section of it on the enclosed plan of Mr. Schick's shows that at some time or other the vaulting collapsed, and was then restored. In Mejir ed Din's "Uus el Jelil," Cairo edition, Arabic, pp. 633-643, is a long account of the circumstances connected with the break-down and the restoration. I shall tell the story briefly. It seems that up to A.H. 878, circa A.D. 1473, the only way of access "to the mosque with minaret belonging to the Moslems and abutting on to the Keniset el Yehud, or Jewish Synagogue in Harat al Yenud," was by a long narrow lane leading from the south. Owing to heavy rains, a house, belonging to the Jews, and situated due west of the mosque, fell in, and the Moslems thought that now was a good opportunity for securing a shorter road of access to the mosque from the great thoroughfare of Harat al Yehud, which passes west of it. They accordingly laid claim to the ruined house, and, it would seem, opened a new lane. These violent proceedings on the part of the Mohammedans were, as a matter of course, protested against by the Jews, who produced documentary evidence that the house that had fallen in was theirs, and was not, as had been asserted by their opponents, mosque property. The case was tried before a Medjlis, or "Tribunal," the members of which are mentioned by name, and one of whom was Mejir ed Din himself. As the court could not agree in their decision, some favouring the Jews, and others the Moslems, the latter appealed to the Sultan Al Malik Al Ashruf, Abu Nusr Kayet bai at Cairo, who sent a Commissioner to Jerusalem to investigate the affair. A fresh Medjlis was held, the result of which was the closing of the Synagogue itself. The Jews appealed to the Sultan in their turn, and, after considerable litigation, they were allowed to re-open their place of worship, the sentences of most of the Ulema at Cairo being in their favour, and their right of possession being confirmed by an official decree of the Sultan's A.H. $879=$ A.D. 1474. "So the Jews took posses- 
sion thereof and entered in them," says Mejir ed Din, "and this caused great vexation to the Moslems, for the Jews manifested great joy thereat, and they hanged up curtains therein and kindled lamps." They were not, however, left in undisturbed possession. Their enemies accused them to the Sultan of having heavily bribed various persons in order to obtain a favourable sentence, and so the law-suit began afresh. The narrative of Mejir ed Din gives us glimpses of stormy scenes in the court, and at last, after an apparently more than usually tempestuous sitting on Monday the 4th of Rajib, "the Sheikh Mohammad bin Afeef ed Din, and they that were with him, went to the Synagogne and ordered its demolition. So the Moslems hastened to demolish it, and they broke down the upper part thereot, and the next day they demolished the rest, and it was a notable day, and Sheikh Abu l'Azm encouraged the people to the demolition, and strengthened them in their purpose, and whenever the clouds of dust rose over the heads of the people and settled on their garments he brushed it off with a mandeel (veil or handkerchief) he had in his hand, and told them that this was of the dust of Paradise, and that in Paradise they would be rewarded for what they had done." The Sultan was of course furious to hear of the destruction of the Synagogue without his orders, and commanded the chief offenders to be arrested and conveyed to Cairo. The hero of the handkerchief episode, however, fled to Mecca and thus escaped punishment. The others were bastinadoed, one fanatic miscreant, to the disgust and vexation of the Sultan, assuming the air of a martyr and saying "Allah akbar," \&c., all the time he was being punished, instead of saying "Al hagg," i.e., "It is just," or "I have deserved this," as the Sultan ordered him to do. Mejir ed Din's quaint narrative then goes on to relate how the Sultan sent a Commissioner to rebuild the Synagogue, and how the latter was lampooned by the Mohammedans for executing his master's orders, \&c.

II.

Mejir ed Din gives us a list of the different Moslem Colleges in Jerusalem in his day. One of these (popularly known as the house of Al Malik ad Daher), but in all probability that mentioned by him as the Tazieh College es-Silsileh after climbing up from the Wailing Place to the great causeway from Wilson's Arch. It is figured on p. 14 of Dr. Philipp Wolff's "Jerusalem" (Leipzig, 1862). Just west of this an archway spans the Tarik Bab-es-Silsileh, and its northern side rests partly on massive fragments of columns and partly on a pier of masonry which hides the façade of a crusading building. Through a broad doorway in this pier one gains access to a large and beautifully-vauited chamber, the roof of which is borne up by two columns in situ, with mediæval capitals, from the sides of which ribs run up the roof. The chamber is full of 
earth and stones, and, at present, it is impossible to ascertain its complete size, as walls of rubble have been built across it. The roof evidently stretche over these walls northwards and eastwards, how far one cannot tell. The old doorway, behind the more modern one in the pier, is undoubtedly Crusaders' work, as is clear from the characteristic diagonal dressing. I think this vault was once the western end of the Church of St. Giles. As you go eastward from this place towards Bab-es-Silsileh you notice on your left hand a small street leading down steps from the causeway to "El Wad." Half-way down the steps, on your right, or on the eastern side of the small street, is the door to the house of the Yousef Effendi of Sir Charles Warren's days, and immediately opposite the entrance through a passage to a long courtyard, in a house which for many years past has been occupied by Georgian Jews, here, some years ago, Dr. Chaplin discovered some more columns, which he believes belonged to St. Giles'. With the exception of a base, not in situ, these have been removed. The Tazieh College lies just between this house and the pillared chamber above mentioned, in the story above which one detects a Crusader's window, with moulding like a curved row of backs of books, just like that seen over the portals to the Church of the Sepulchre. This window is half hidden behind a house built on the top of the arch spanning Tarik Bab-es-Silsileh, as above stated. I tried, but unsuccessfully, to get leave to enter and inspect the chambers in the so-called house of Melek ad Daber, which is just east of the vaulted chamber.

\section{III.}

"The position of the Church of St. John" the Evangelist, says a footnote to p. 24 of the Pilgrim Text Society's "City of Jerusalem," is not known. "The cross-roads," where the text describes it as having been situated, "seem to have been at the corner of the Via Dolorosa, south of the Armenian Catholic Monastery, No. 27 Ordnance Survey."

I would call attention to the fact that just at the point indicated, south of the road, at the place where is the Ordnance Survey Benchmark 2420-6, opposite the Austrian Hospice, there is a remarkable ruined medirval house, two lower vaults of which are still entire, one (in Sir C. Warren's time the Palestine Exploration Fund's Store) being now occupied by stone-cutters, and having in the south-east corner of the floor a shaft leading to a vault at a lower level, perhaps a cistern, full of earth, and the other being used as a stable. These vaults, which are about 30 feet long and 15 wide, lie side by side, north and south, and form a platform on the top or roof of which are the remains of a small church, of which the chancel-arch and part of the side walls still remain. This building lies east and west. A mihrab or Moslem-prayer niche, built in diagonally under the chancel-arch between two arched recesses which look like miniature apses, but are perhaps only walled-up windows, leaves no doubt that when the Holy City fell into the hands of the Mohammedans, they turned the place into a mosque, and then, as is 
their way, allowed it to fall into ruin. These remains are, as I was told on the spot, called El Jami 'el Ahmar. My thanks are due to the Rev. H. K. Harris, of Runwell Rectory, Wickford, Essex, for the enclosed photograph of this interesting ruin, which I think we may regard as that of St. John the Evangelist.

The note in the last Quarterly on the Crocodile from the Zerka reminds me that last winter a true leopard (not a cheetah) that had done a good deal of mischief to the flocks and cattle of Bir Zeit and the neighbouring villages north of Jerusalem, was shot by a fellah from Hizmeh. Its skin, which I saw whilst still fresh, wás bought by Dr. Merrill.

Another popular version of the story told in M: P. Baldensperger's interesting paper on Fellahin Folklore is that the woman who made a wrong use of the hot loaf of bread instantly fell down on: her face upon the round straw mat which covered the batieh or circular wooden dish in which the dough is kneaded. This latter (the batieh) was overturned upon her back, and, as a punishment for what she had done, the woman was turned into a tortoise, the batieh becoming the carapace, and the straw mat, or "tabbak," the under shell. Her child was changed into a monkey. The bare red seats of monkeys are the hereditary effects of the hot loaf applied to the back of their ancestor: A marriage procession passing was, as M. Baldensperger relates, turned into a number of stones.

\section{NOTE ON AN ANCIENT WEIGHT FOUND AT GAZA.}

\section{By Professor Clermont-Ganneau.}

ONE of my former pupils, M. l'Abbé Chabot, who has recently had occasion to visit Gaza, has just sent me copies of various antiquities he has seen there. Among them is a square leaden weight, weighing 144 grammes, with the following inscription in relief :- :

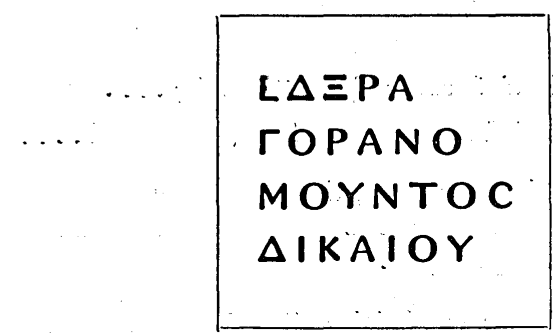

My reading of it is-

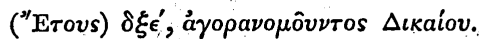

"Year 164, Dikaios being agoranomos." 